\title{
Record Keeping Management for Effective Administration of Secondary Schools in Nigeria
}

\author{
Ebenezer Oyetide Olalere ${ }^{1}$ (Corresponding author) \\ Baptist Mission Schools of the Nigerian Baptist Convention \\ 22, Awolowo Avenue, Bodija, Oyo State, Nigeria.
}

Tel: 234-805-224-1184 E-mail: director@baptistmissionschoolsnbc.org

\begin{abstract}
Bosede Ladoba ${ }^{2}$, Kayode Oladapo ${ }^{3}$, Hezekiah Alamu ${ }^{4}$, Bayonle Bamidele ${ }^{5}$, Josiah Innocent ${ }^{6}$, Moses Adeojo ${ }^{7}$, Baptist Mission Schools of the Nigerian Baptist Convention 22, Awolowo Avenue, Bodija, Oyo State, Nigeria.

E-mail: hhr@baptistmissionschoolsnbc.org 2, hict@baptistmissionschoolsnbc.org ${ }^{3}$,hqai@baptistmissionschoolsnbc.org ${ }^{4}$, hof@baptistmissionschoolsnbc.org ${ }^{5}$, hoa@baptistmissionschoolsnbc.org ${ }^{6}$, amao@baptistmissionschoolsnbc.org ${ }^{7}$
\end{abstract}

The research is financed by The Directorate of Baptist Mission Schools (The Directorate of Baptist Mission Schools (BMS) is primarily responsible for the establishment and effective management of Secondary Schools owned by the Nigerian Baptist Convention.)

\begin{abstract}
The aim of the study was to find out the extent to which management practices in record keeping will affect the effectiveness of secondary schools administration in Nigeria. A descriptive survey design was used and a sample of 255 staff members randomly selected from all 15 schools of the Baptist Mission Schools of the Nigerian Baptist Convention was used for the study. Two hypotheses guided the study. Data were collected using a questionnaire entitled "School Record Keeping Management Practices Questionnaire (SRKMPQ)". Data were analysed using multiple regressions and t-test statistics. The result of the study revealed management practices in record management had a significant relationship in the effectiveness of secondary schools administration. The management practices variables made significant contribution in the determining effective secondary school administration in Nigeria through record keeping. Premised on the findings of the study, it was recommended that each school administrator should set out guidance that will encourage appropriate standards for record keeping. Other suggestion included sufficient training and retraining on the importance of the records keeping, the technicalities of managing them and finally adoption of information and commutation technology for school record keeping management.
\end{abstract}

Keywords: Record Keeping, Management, Managerial Practices, Administration, Secondary Schools DOI: $10.7176 / \mathrm{JEP} / 12-1-10$

Publication date: January $31^{\text {st }} 2021$

\section{Introduction}

Education is now a global service that every country strives to provide for its citizens since it serves as a tool for socio-economic development. The economy of all countries all over the globe, become more dependent on this sector as the long-run contribution of educational sector to employment and national development thus impacting on Gross Domestic Growth of the country. The purpose of education can only be achieved through effective administration which helps to bring about an optimum achievement and one of the most important aspects is record keeping (Alabi, 2017). The adequate keeping of records over the years has given the educational administrators ability to unveil interesting knowledge from educational-related data that could assist in effective management of schools in the 21 st century. School records are official documents, books and files containing essential and crucial information on actions and events which are kept and preserved in the school offices for utilization and retrieval of information when needed (Durosaro, 2002). Such records are kept by principals, teachers, counsellors and the administrative staff and these records are essential because they affect all areas of school management such as budgeting, planning, staffing, facilities among others. This study investigated the management of school records for effective administration of secondary schools in Nigeria.

\subsection{Statement of the problem}

With respect to the significance of record keeping in schools for the achievement of the aim of school creation, it was observed that these records were not adequately managed by the school administrators. Despite the main purpose of record keeping in the school system, the management of records in secondary schools in Nigeria still left much to be desired for effective administration. This suggests that school record keeping management practice 
in Nigeria has a number of issues. Based on these facts, it is glaring that a problem exists and this is the concern of this study.

1.3 Research Question

The study will address the following questions:

1. What management practices improve the record keeping in secondary schools?

2. How does record keeping management improve school administration?

1.4 Hypothesis

Based on this study, the following hypotheses were formulated to be tested:

$\mathrm{H}_{\mathrm{O} 1}$ : There is no significant relationship between management practices and record keeping in secondary schools $\mathrm{H}_{\mathrm{O} 2}$ : There is no significant relationship between record management and effectiveness of secondary schools administration.

1.5 Justification of the study

The function of school establishment is not limited to teaching alone but ensuring the smooth running and adequate accountability from those appointed to manage the schools affairs. This study will be of relevance to the stakeholders (staff, parents and students), school management board and the entire society, it will expose the school administrators to the best management practice in keeping school records and serve as an eye-opener on the need to provide necessary and reliable information for accurate school documentation.

\subsection{Literature Review}

\section{$2.1 \quad$ Theoretical Framework: Theory of Achievement}

David McClelland is most noted for describing three types of motivational need namely achievement motivation (n-ach), authority/power motivation (n-pow) and affiliation motivation (n-affil) which he identified in his 1961 book. These needs are found in varying degrees in all workers and managers, and this mix of motivational needs characterizes a person's or manager's style and behaviour, both in terms of being motivated in the management and motivation of others.

McClelland stated that most people possess and exhibit a combination of these characteristics. Some people exhibit a strong bias to a particular motivational need and this motivational or needs 'mix' consequently affects their behaviour and working/managing style. McClelland suggested that a strong n-affil 'affiliation-motivation' undermines a manager's objectivity, because of their need to be liked, and that this affects a manager's decisionmaking capability. A strong n-pow 'authority-motivation' will produce a determined work ethic and commitment to the organisation, and while n-pow people are attracted to the leadership role; they may not possess the required flexibility and people-centered skills. McClelland argues that $n$-ach people with strong 'achievement motivation' make the best leaders, although there can be a tendency to demand too much of their staff, with the belief that they are all similarly and highly achievement-focused and results driven, which of course most people are not.

McClelland's particular fascination was for achievement motivation, and this laboratory experiment illustrates one aspect of his theory about the effect of achievement on people's motivation. McClelland asserted via this experiment that while most people do not possess a strong achievement-based motivation, those who do, display a consistent behaviour in setting goals:

Volunteers were asked to throw rings over pegs rather like the fairground game; no distance was stipulated, and most people seemed to throw from arbitrary, random distances, sometimes close, sometimes farther away. However, a small group of volunteers, whom McClelland suggested were strongly achievement-motivated, took some care to measure and test distances to produce an ideal challenge - not too easy, and not impossible. Interestingly a parallel exists in biology, known as the 'overload principle', which is commonly applied to fitness and exercising, ie., in order to develop fitness and/or strength the exercise must be sufficiently demanding to increase existing levels, but not so demanding as to cause damage or strain. McClelland identified the same need for a 'balanced challenge' in the approach of achievement-motivated people.

McClelland contrasted achievement-motivated people with gamblers, and dispelled a common pre-conception that n-ach 'achievement-motivated' people are big risk takers. On the contrary - typically, achievement-motivated individuals set goals which they can influence with their effort and ability, and as such the goal is considered to be achievable. This determined results-driven approach is almost invariably present in the character make-up of all successful business people and entrepreneurs.

McClelland suggested other characteristics and attitudes of achievement-motivated people:

- achievement is more important than material or financial reward.

- achieving the aim or task gives greater personal satisfaction than receiving praise or recognition.

- financial reward is regarded as a measurement of success, not an end in itself. 
- $\quad$ security is not a prime motivator, nor is status.

- feedback is essential, because it enables measurement of success, not for reasons of praise or recognition (the implication here is that feedback must be reliable, quantifiable and factual).

- achievement-motivated people constantly seek improvements and ways of doing things better.

- Achievement-motivated people will logically favour jobs and responsibilities that naturally satisfy their needs, i.e. offer flexibility and opportunity to set and achieve goals, e.g., sales and business management, and entrepreneurial roles.

McClelland firmly believed that achievement-motivated people are generally the ones who make things happen and get results, and that this extends to getting results through the organization of other people and resources, although as stated earlier, they often demand too much of their staff because they prioritize achieving the goal above the many varied interests and needs of their people.

\subsection{Conceptual Review}

Record keeping is a germane factor in determining the effectiveness and efficiency of the school system. In fact, it is central in the administration of institution of learning because it documents the planning and implementation of appropriate course of service allowing proper monitoring. In conventional paper-based organizations, paper continues to be viewed as the material for records in administrative documentations (Odeniyi \& Adeyanju, 2020). Records must be comprehensive, available, accessible and secure. This implies that records must contain adequate information which is needed for the smooth running of school activities. School records are grouped into statutory and non-statutory. Statutory records include admission/withdrawal register, attendance register, scheme of work, time-table, logbook, visitors' book (educational policy book), time/movement books, school diary, lesson plan/note for teachers, examination record book, punishment book, staff minutes book, inspection/supervision report file, etc. Non-statutory records are cash book, stock book, school calendar, inventory book, school magazine, confidential report forms and requisition book. The term" school record management" tends to capture those various meaningful activities and roles rendered by school administrators (principals and staff) to maintain and keep an up-date regarding the school. School record management is of paramount value, this is because it is the basis through which effective and efficient school administration can be achieved. Generally speaking, record management deals with the documentation of data to its atmost update towards achieving any organizational goals. On the other hand, the efforts of school principals and staff to preserve and retrieve the information of an individual staff and student and making use of them when need there is a need is herein referred to as school record management. Iwhiwhu (2005) stressed the insufficient quality and quantity of manpower in record management in the school system. He emphasized that manpower is employed without prejudice to qualitative records management. Though this business of record keeping and effective management in the secondary school system has not attained good success due to insufficient provision of facilities, fund and management components however, adequate security, storage facilities and funds are generally recommended for good record keeping and management. Caroline (2012) explains formative and summative assessments. She averred that "formative assessment takes place before or during the instruction, with the explicit purpose of eliciting evidence that can be used by students and teachers to improve the current learning, while summative assessment is a measure of learning at a particular point in time" This means that formative is the pre-assessment done before the end of the exercise while summative is the addition or the total assessment done after the whole exercise. Therefore, some records that constitute formative assessment in schools include: lesson plan, time-table, attendance register, log book, and diary while summative records in schools are termly record/result sheet, termly hostel report, students' payment voucher, class description and a host of others.

\subsection{Empirical Review}

Uzoho (2006), investigated the record keeping practices of secondary school principals in Umuahia Education zone of Abia state and the problems associated with keeping of these records. To carry out the study effectively. Four research questions and two null hypotheses were formulated, descriptive survey design was adopted. A 28questionnaire item was developed and administered to 420 urban and 180 rural secondary school teachers in Umuahia Education zone of Abia state. Mean scores were used to answer the four research questions while the ttest statistics was used to test the null hypotheses formulated for the study. Results or findings were as follows; urban and rural secondary school teachers in Umuahia Education zone indicated that records presently kept in their schools include admission register, attendance register, staff minutes book, school time table, school accounts book, academic records of students and copies of schools rules and regulations. There is a slight significant difference between the opinions of urban and rural secondary school teachers on the administrative practices that characterize the keeping of records in secondary school in Umuahia Education zone. These practices include principals delegating the keeping of day to day administrative records to senior teachers, records events as they occur in the appropriate records booklets, keep accurate custody of record materials and books in the offices, check 
every item of information in the records before appending their signatures. There is no significant difference between opinions of urban and rural secondary schools, teachers with regards to the administrative practices that characterize the keeping of records in secondary schools in Umuahia Education zone of Abia State.

Oluwole \& Dondo (2015) investigated record keeping and effective management of secondary schools in Zone B Senatorial District of Benue State, Nigeria. Four research questions and four research hypotheses guided the study. The descriptive survey design was therefore adopted. The population of the study comprised 3,704 teachers from 232 public and private secondary schools in Zone B Senatorial District. A sample of 370 teachers from 23 public and private selected secondary schools constituted the sample of the study. A- 12 item structured questionnaire constructed by the researcher titled "Record Keeping and Effective Management of Secondary Schools Questionnaire (RKEMSSQ)" was used for the collection. Descriptive statistics of mean and standard deviation were used to answer research questions while the chi-square test of goodness of fit was used to test the hypotheses at 0.05 level of significance. The findings revealed that historical records have significant impact on information dissemination and financial records have significant impact on accountability in Zone B Senatorial District of Benue State. Based on the findings of the study, the researcher recommended among other things that, school administrators should imbibe the culture and practice of keeping regular records of students and the activities or events that go on in the school so that if the need arises for use in the future, it will be easily ascertained without any stress and doubt.

Odeniyi \& Adeyanju (2020) carried out a study with the purpose of assessing school record management in FCT secondary schools. The descriptive research design was used for this study. The population was drawn from ten (10) secondary schools in FCT. The instrument for data collection comprised questionnaire titled "Assessment of School Record Management in Secondary Schools in FCT" (ASRMSS). A sample size of eighty respondents from schools was used. Simple percentage was adopted in analyzing the research questions while chi-square was adopted in analyzing the hypotheses. Research findings revealed that the various record books used in schools include: log-book, attendance register, lesson plan, syllabus, staff movement book, visitors' book, admission and withdrawal register, to mention a few. It was also revealed in the findings that most of the records in school are not properly kept. Also, timely supply of school records, availability of funds, teachers' training and proper back up of records were the solutions proffered by respondents. It was however recommended that stakeholders in the school should make use of the school's record books for efficiency purposes.

\subsection{Research Methodology \\ 3.1 Research Design}

The research design adopted for this study was descriptive survey design and considered appropriate for this study because it seeks to describe the management of school record keeping and the variables cannot be manipulated.

\subsection{Population and Sample}

The population comprises all 15 principals and 1,201 staff members in the 15 missionary secondary schools of the Nigerian Baptist Convention across the country. The secondary schools used were

i. Baptist Academy, Obanikoro, Lagos.

ii. Reagan Memorial Baptist Girls' Secondary School, Sabo - Yaba, Lagos

iii. Baptist Girls' Academy, Obanikoro, Lagos.

iv. Baptist Boys' High School, Saje, Abeokuta.

v. Baptist Girls' College Idi-Aba, Abeokuta.

vi. Baptist High School, Benin City.

vii. Baptist Model High School, Jos.

viii. Baptist High School, Jos.

ix. Baptist High School, Makurdi.

x. Olivet Baptist Academy, Oyo.

xi. Baptist High School, Masaka.

xii. Baptist Girls' High School, Agbor.

xiii. Baptist High School, Orerokpe.

xiv. Baptist Model Secondary School, Obinze

xv. Baptist High School, Port-Harcourt

Simple random sampling was used in selecting $20 \%$ of the teachers' population with all the 15 principals summing up to 255 respondents.

\subsection{Research Instrument}

The data collection instrument was a questionnaire titled "School Record Keeping Management Practices Questionnaire (SRKMPQ)". The instrument has two sections. Section A sought personal information about the 
respondents such as gender etc. While section B consisted of 30 items grouped under five clusters that measured $5 \mathrm{sub}$ variables of management practices namely, operations, monitoring, targets, people and leadership which elicited information on the strategies for record keeping management in schools. The instrument was a 4-point response scale. Each item on the instrument had response options ranging from Strongly Agree (SA), Agree (A) to Disagree (D) and Strongly Disagree (SD). The reliability coefficient of the instrument was 0.82 using Cronbach Alpha reliability technique. This was high enough for the instrument to be considered reliable and therefore considered appropriate for use. The instrument was administered on the respondents in their various schools with the help of google form. Copies of the instrument were filled and returned online correctly.

\subsection{Results}

The technique used for data analysis was multiple regression in finding out the combined relative contributions of management practices in school record keeping for effective administration of secondary schools in Nigeria.

$\mathrm{H}_{\mathrm{O} 1}$ : There is no significant relationship between management practices and record keeping in secondary schools. The sub-variables of management practices used in this study included operations, monitoring, targets, people and leadership. The dependent variable was school record keeping. The result of multiple regression analysis is presented on Table 1.

Table 1: Relative contribution of management practices to record keeping in secondary schools

\begin{tabular}{lllll}
\hline Management Practice Variables & $\mathrm{B}$ & $\mathrm{SE}$ & Beta & T-ratio \\
\hline 1. Operations & 0.125 & 0.053 & 0.129 & $2.435^{*}$ \\
2. Monitoring & 0.130 & 0.045 & 0.127 & $2.706^{*}$ \\
3. Targets & 0.126 & 0.058 & 0.112 & $2.257^{*}$ \\
4. People & 0.134 & 0.049 & 0.140 & $3.082^{*}$ \\
5. Leadership & 0.0163 & 0.064 & 0.150 & $3.651^{*}$ \\
\hline$<.05 ;$ Constant $=9.345$ & & & &
\end{tabular}

Table 1 shows for each component of management practices unstandardized regression coefficient (B), Standard Error (SE), Standardized Coefficient (Beta) and T-ratios. Thus, table 1 reveals that Leadership $(\mathrm{t}=3.652 ; \mathrm{p}<.05)$, People $(\mathrm{t}=3.082 ; \mathrm{p}<.05)$, Monitoring $(\mathrm{t}=2.706 ; \mathrm{p}<.05)$, Operations $(\mathrm{t}=2.435 ; \mathrm{p}<.05)$ and Targets $(\mathrm{t}=2.257$; $\mathrm{p}<.05)$ in that order, relatively make significant contributions to school record keeping management in Nigeria. The finding revealed that Leadership is the most potent management practice and targets, the least.

$\mathrm{H}_{\mathrm{O} 2}$ : There is no significant relationship between record management and effectiveness of secondary schools administration.

Table 2: Summary of multiple regression of the relationship between record management and effectiveness of secondary schools administration in Nigeria

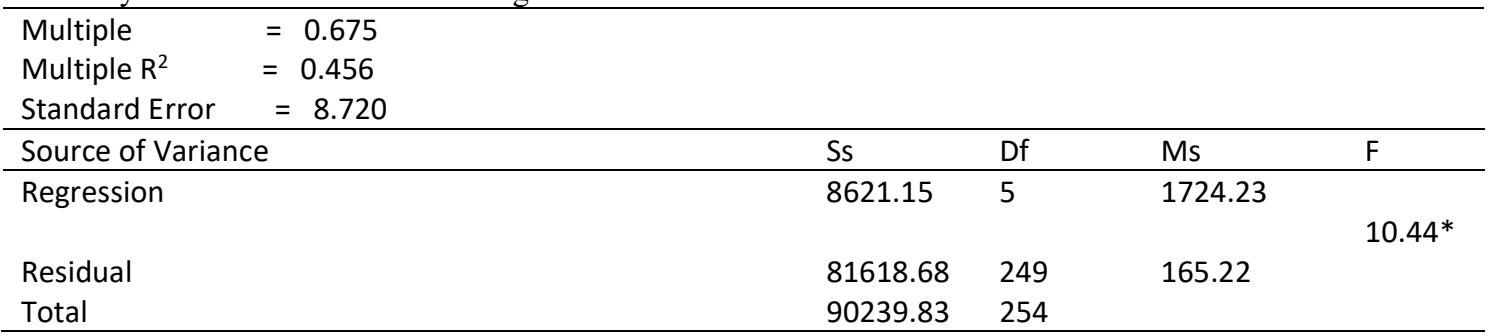

$* \mathrm{p}<.05 ; \mathrm{df}=5$ and $254 ;$ Critical-F $=2.21$

Table 2 reveals a positive significant relationship between the joint variables of record management practices (operations, monitoring, targets, people and leadership) and effectiveness of secondary schools administration in Nigeria $(r=0.675 ; p<.05)$. The multiple $\mathrm{R}^{2}$ value of 0.456 depicts $45.60 \%$ of the variance in determining effective secondary schools administration is accounted for by record management practices. The result of analysis of variance gave F-value of 10.44. This is greater than the critical F-value of 2.21 needed for significance at 0.05 level of significance with 5 and 254 degrees of freedom. This means that the sub-variables of record management practices jointly contribute to the effectiveness of secondary schools administration in Nigeria. With this result, the null hypothesis is rejected.

\subsection{Discussion of Findings}

The findings in this study reveal that management practice variables when joined together significantly have 
relationship with record keeping thus enhancing effective secondary schools administration in Nigeria. This means that effective secondary schools administration does not happen by chance. One of the findings reveals that leadership is the most potent management practice and targets the least. This research finding could be attributed to the fact that administrators of secondary schools used for this study have realized the need to effectively manage the school records for enhancement of the schools administration. Leadership being the most important practice depicts that there is a relationship between leadership and the keeping of day-to-day school records by staff members. Of course this could be linked to the leadership style of the administrators and their ability to use it for accurate record keeping. The present finding is in consonance with the work of Omoha (2013) who reported that ideal administrative practices by administrators could ensure effective and efficient school record keeping management. The present finding is also in agreement with the research finding of Idoko (2005) which showed that school record management will continue to suffer neglect and misappropriation unless school administrators employ desirable strategies for improving on school records keeping. However, the responsibility for school records lie squarely on the shoulders of the chief executive of the school who is the school head (Omoha, 2013).

The finding of the study also shows that people (human resources) relatively contribute to record keeping management for effective secondary school administration. This means that people (human resources) as a component of management practice is a strong factor in record keeping management for effective school administration. The finding depicts that there is a relative relationship between school record keeping and the calibre of people (human resources) who ensure the records are accurate. Effective management of people (human resources) reduces errors and enhances record keeping management. It also enhances school administration. This finding agrees with the work of Ajayi and Ayodele (2002) identifying laziness and apathy on the part of staff members lead to poor handling of school records. (Gama, 2010) also recommended that people should be sufficiently trained and retrained on the importance of the records they generate and receive and be acquainted with the technicalities of managing them.

The third finding in this study shows that monitoring significantly has a relationship with school record keeping management for effective secondary school administration in Nigeria. This means that monitoring is an important variable of management practices that can enhance school record management for effective secondary school administration in Nigeria. Effective monitoring focuses on the monitoring of performance and reviewing the results of record keeping, the dialogue between the task within the school and the consequences of anomalies in the processes involved. This finding is in agreement with the research work of (Alabi, 2017) which postulates that without appropriate, adequate and relevant record management there cannot be effective and efficient administration of secondary schools in Nigeria.

The present study also reveals that the operations of record keeping management contributes to the effectiveness of secondary school administration. The finding in this work could be attributed to the effective leadership skills of secondary school administration. It also depicts that the concern of the school leadership with the standardization of processes and adoption of best management practices within the school reach for record keeping management depends to a large extent on the school leadership styles of administration. Experienced supervisors are able to follow the trend of educational development within a school (Bosah, 2011). Administrators of the secondary schools used for this study must have seen the need to use their leadership style to make staff members have sense of responsibility in the operation of record keeping management for effective secondary school administration in Nigeria. According to Ogbonnaya (1994), it is the administrative responsibility of both principals and teachers to embrace ideal administrative practices that ensure effective and efficient records keeping in school system.

The study also reveals that meeting the targets of the school that is, the purpose for which it was established can only be achieved through effective administration. There is no other way by which the school can achieve the purpose of its establishment other than effective administration and one of the potent aspects of school administration is effective record management. Akporhonor (2011) maintains that records serve as important sources of information that enable individuals and organizations to carry out their legal obligations. So, maintenance of these records would no doubt facilitate decision making as well as enhance the general administration of the school system.

\subsection{Conclusion and Recommendations}

From the findings of this study, it could be concluded that management practice variables namely operations, monitoring, targets, people and leadership are significant record keeping management thus enhancing the effectiveness of secondary schools administration in Nigeria. This shows that management practices have a role to play in record keeping management for effective administration of secondary schools in Nigeria. Therefore, how each school administrator manages the various aspects of managerial practices to that extent will determine 
the efficient of record keeping management and how effective the administration will be in Nigeria. It recommended that each school administrator should set out guidance that will encourage appropriate standards for record keeping, sufficient training and retraining on the importance of records keeping and the technicalities of managing them. Finally, accept that this era of human kind is characterised as an information age, where the whole world is experiencing and interacting with a new revolution that has changed the traditional way of record keeping into a completely different approach through the adoption of information and communication technology for school record management.

\section{References}

Ajayi, I. A., \& Ayodele, J. B. (2002). Fundamentals of Educational Management. Ado-Ekiti: Greenline Publishers. Akporhonor, B. A. (2011). The challenges of records management in university libraries in South-South zone of Nigeria. Communicate: Journal of Library and Information Science 13 (1). 23 - 34.

Alabi, A. O. (2017). Records Keeping For Effective Administration of Secondary Schools. Journal of Public Administration and Governance, 7(2), 66. https://doi.org/10.5296/jpag.v7i2.11182

Bosah, H, O. (2011). Dynamics of Educational Administration and Management. Awka: Meks publishers Ltd. Records keeping in Nigeria Schools (pp. 19-47). In Ndu, N., Ocho, L.O \& Okeke, B.S. (Eds)

Caroline, W. (2012). Teachers formative and summative assessments. Journal of Research and Development Connections. 3(2): 6-15.

Durosaro, D.O. (2002). Management of school records. In F. Durosaro \& S. Ogunsaju (Eds.) The craft of educational management. (pp. 138-152). Ilorin: Indemac.

Gama, U. G. (2010). A survey of records management practices in circular primary schools in Metropolitan Local Government Area (MLGAs) of Kano State. Samaru Journal of Information Studies, 10(1\&2), 23-30.

Idoko, A.A. (2005). Understanding School management. Makurdi: Ugo Printing Press. Jones,

Iwhiwhu, B.C. (2005). Records keeping in schools: A new paradigm for effective school management. www.managerial.com. Retrieved August 6th, 2007.

Odeniyi, O. ., \& Adeyanju, A. . (2020). Assessment of School Record Management in Secondary Schools in Federal Capital Territory. Open Journals of Educational Development (OJED), 1(1), 54-65.

Ogbonnanya, N.I. (1994). Appraisal of Record Keeping Practices of Principals in Abia State Secondary Schools. Review of Education 2(11), 28.

Oluwole, M., \& Dondo, I. E. (2015). Record Keeping and Effective Management of Secondary Schools in Zone B Senatorial District of Benue State, Nigeria. European Open Educational Research Journal, 1(1), 1-13. http://eurpub.com/journals.php

Omoha, F. . (2013). Management of School Records in Secondary Schools in Otukpo Education Zone (Issue December). University of Nigeria, Nsukka.

Uzoho, K.C. (2006). Record Keeping practices of secondary school principals. Unpublished M.Ed Thesis. Dept of Education, Abia state University. 